WellBeing International

WBI Studies Repository

1986

\title{
The Psychology and Ethics of Humane Equine Treatment
}

Sharon E. Cregier

University of Prince Edward Island

Follow this and additional works at: https://www.wellbeingintlstudiesrepository.org/acwp_ewp

Part of the Agribusiness Commons, Animal Studies Commons, and the Business Law, Public Responsibility, and Ethics Commons

\section{Recommended Citation}

Cregier, S.E. (1986). The psychology and ethics of humane equine treatment. In M.W. Fox \& L.D. Mickley (Eds.), Advances in animal welfare science 1986/87 (pp. 77-87). Washington, DC: The Humane Society of the United States.

This material is brought to you for free and open access by WellBeing International. It has been accepted for inclusion by an authorized administrator of the WBI Studies Repository. For more information, please contact wbisr-info@wellbeingintl.org.

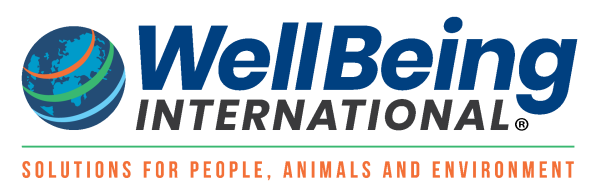




\title{
THE PSYCHOLOGY AND ETHICS OF HUMANE EQUINE TREATMENT
}

\author{
Sharon E. Cregier ${ }^{1}$
}

\section{Introduction}

The effect on animals of man-induced stressors, such as the disruption of herd bonds, stabling, medication procedures and the like, has been the subject of increasing investigation. Obvious and shocking abuses against animals, bullfighting, certain training practices in the racehorse industry, and rodeo events such as wild horse races, steerbusting or calf-roping, are readily recognized and have, in some instances been stopped. (Steerbusting refers to roping, from horseback, of running cattle in such a manner as to flip the animal backward or jerk it down, knocking the wind out of the animal and occasionally breaking ribs, vertebrae, and neck.)

However, the bulk of incidents of abuse is in commercial associations between man and animal (Fraser 1982). These are the animals whose troubles are not obvious but who suffer pain and discomfort nonetheless. The abuses may be unwitting and remediable by education, or deemed to be without remedy. One such major abuse occurs during the transport of animals.

\section{Transport: A Model of Albuse}

Transport procedures involve bond and territorial disruption, forced driving, crowding, subjection to poisonous fumes from petrol, diesel or battery acids; sudden restraint; and subjection to erratic vehicular movement. For the utilized animals in agribusiness and elsewhere, transport causes more episodes of stress than any other common husbandry practice (Fraser 1982).

Horses, by nature neophobic, fragile, timid, and the most defenseless of hooved domestic animals, are especially distressed by transport (Sambraus 1981). Their distress is manifested by active and powerful resistance at the loading site, halter and hobble abrasions incurred during transport, vocalizations, kicking, choking from fear (sometimes to death), dehydration, and orosthenia (energetic mouthing activities; Fraser 1984), such as aggressive biting of companions in transit or rapid and erratic ingestion of feed during transit.

To control these symptoms of resistance by the horse, an extensive array of coercive paraphernalia has been developed to assist in the transport process: electric prods, whips, ropes, halters with steel or chain nosebands, crushes, hobbles, and punishment administered via electric shock from the driver's cab 
should the animal "misbehave" during transport. Although the use of these coercive devices actually exacerbates the situation which they are supposed to contain, and often poses increased danger to the handler and animal, their popularity as selling items in livestock periodicals remains unabated.

Current research has demonstrated conclusively that horses suffer pain and discomfort, and are in danger of injury and death, when they must travel in the trailers and trucks that almost all haulers of livestock now use (Cregier 1982). These conveyances force the equine passenger to travel facing the engine, a position which-on loading, braking, during traffic maneuvers, and unloading-violates the basic attributes of equine physiology and psychology.

When the conventional conveyance moves off, the horse is thrust backward off its forequarters. When the conveyance brakes, the horse is pitched forward at the original rate of speed of the conveyance. The largest number of horse trailer injuries seen by one veterinarian are those to the horse's head, throat, and chest (F. Horney, personal communication, 1980).

In an attempt to mediate between the two opposing actions and protect its vulnerable head from injury on braking, the horse travels with most of its weight thrust toward its hindquarters, an area of its anatomy designed by nature to carry only $30-35 \%$ of its weight for sustained periods. In order to maintain the increased weight thrust on its hindquarters, the horse will abduct a hindlimb, placing strain on its pubio-femoral ligament and its sacroiliac and sacrolumbar junctions.

Transport stressors frequently result in horses being stiff, exhausted, dehydrated, and ill on arrival at destination, even after a comparatively short journey (Abbott 1979; Messer 1976; Owen et al. 1983). Blood tests on transported horses reveal an increase of packed cell volume (PCV), dehydration, a drop in calcium levels, a rise in cortisol and glucose levels, and a rise in serum creatinine and creatine phosphokinase (CPK) levels associated with muscular exhaustion (Caola et al. 1984).

Two types of trailers have been designed conducive to the horse's behavioral and anatomical requirements for security and balance. The original, known as the Kiwi Safety Trailer, developed in the late 1960s, was designed by a New Zealand horseman and engineer. The NZ design eliminates the natural objection of horses to entering a dark chamber (the entry system used in most road transport for horses) by virtue of teaching the horse to step parallel to the entry upon a platform, turn, and then reverse into the trailer.

Throughout the loading, the handler remains at the horse's head; no coercive tactics are used; passive, familiar aids to the horse, such as haybales for guidance, are used; and no activity takes place at the horse's blind spot - its hindquarters.

To unload, the platform is lowered to a ramp and the horses are quickly led out singly or together by one person (figure 1), an important consideration aiding the rescue when tow vehicles have caught fire. 
To accommodate the change in cargo weight placement in the trailer, the axles are moved about $1.2 \mathrm{~m}$ (approximately four feet) forward from their position in conventional transport. The axle change places the trailer's center of gravity closer to that of the tow vehicle's and directly under the horse's center of gravity when it stands at ease, leaning over its forequarters. The change facilitates emergency braking. This design is the only such in the world that can stop within 9 meters (approximately 30 feet) at $32.2 \mathrm{~km} / \mathrm{hr}$ (approximately $20 \mathrm{miles} / \mathrm{hr}$ ), without upsetting the horses or jackknifing the vehicle.

During transit, the horse maintains its weight over its forequarters, which is the normal manner of a sound horse; lowers its head; and travels with one or the other hind hip in a resting position, quite unlike the straddling which horses subjected to conventional transport must do. (Trailers meeting these design criteria are available from Stratford Motor Body Builders, Stratford, New Zealand.)

Recently a North American-designed rear-face trailer has been developed. Unlike the NZ design, it requires the horse to load into the conveyance from a ramp at the bulkhead. Thus the bulkhead is not featureless, like the NZ

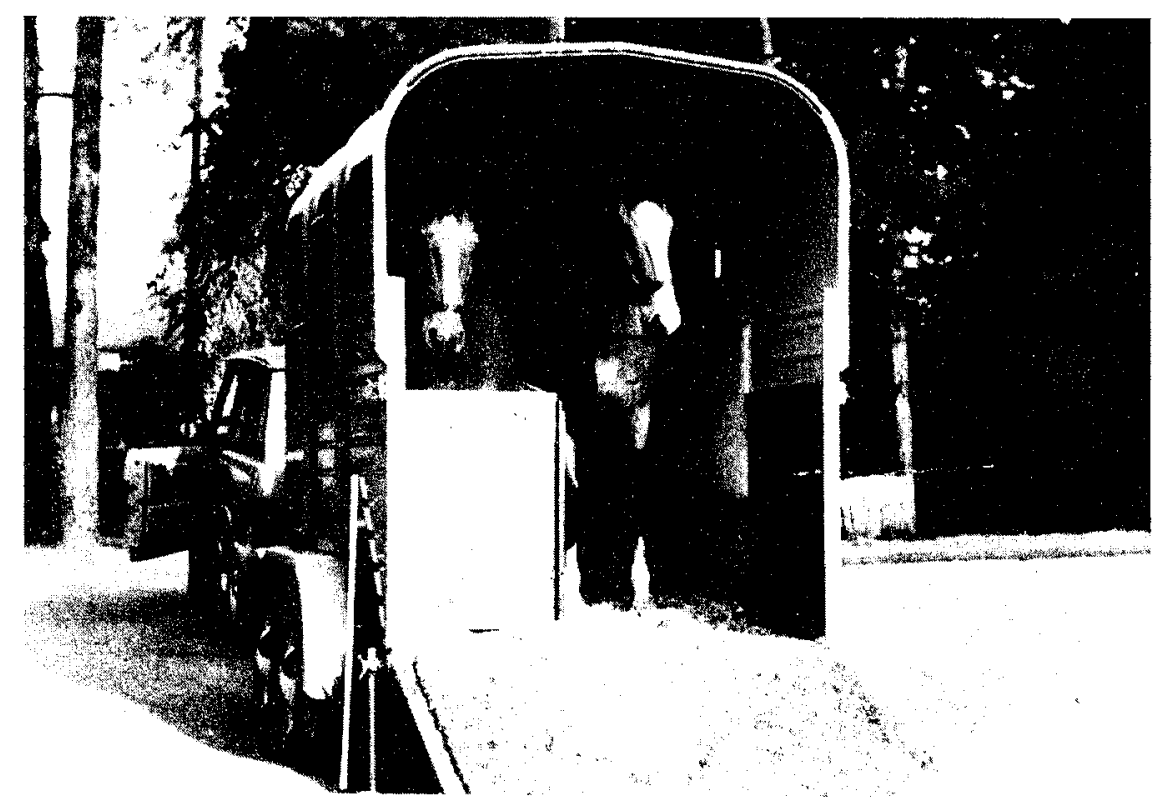

Figure 1. Reversed into the New Zealand design trailer from a platform, horses avoid facing a dark hole for loading. Fleshy buttocks are presented to a featureless bulkhead. Heads may be lowered for keeping nasal and throat passages drained. The horse's vulnerable head, throat and chest are no longer pitched forward on braking, nor is there any threatening activity in its rearward blind spot. (Photo: Courtesy of Rice Trailers.) 
design, but utilizes a butt-bar. This device is traditional in conventional transport systems to prevent the horse, with varying degrees of success, from bursting backward toward a possible escape.

As in the NZ design, the horse may be led out by one person down a ramp at the rear of the trailer. Other features-such as the location of the trailer's center of gravity beneath the horse's balance center, and a tethering system that allows the horse to balance effortlessly with its head and thoracic sling (the latter acting much like a gimbal) - incorporate features of the NZ design. (Trailers meeting these design criteria are available from About Face Trailers, 1975 Bee Canyon Rd., Arroyo Grande, CA 93420.)

\section{Resisting Improvements in Animal Welfare}

It would seem that the bulk of transport problems of horses-e.g., those pertaining to security from attack behind, blows to the head and chest, injuries to fetlocks and pasterns, exhaustion upon arrival - are well on their way to being solved. But work in this area has demonstrated something else. It has shown that reasoned explanation of the rear-face concept has not, by itself, been enough to convince horsemen that they should do something about the abuses of transporting horses in the conventional way.

Humane workers must deal regularly with many people who, while not themselves inhumane or indifferent to suffering, will argue that animals have always suffered and always will. It has been noted that the human eye very quickly becomes accustomed to the grotesque and to deformities. Examples in the equine world are the built-up shoes on Tennessee Walking horses, forcing the horse to travel unbalanced and requiring caustic agents to sustain the gait; the contortions of rodeo bucking horses accompanied by their bawls and screams (contortions not occurring in their unhandled states); and the contortionistic efforts of a horse to protect and balance itself in conventional transport. Each are considered "normal" by many people who work with horses.

Others will contend that while some improvements are possible, only excessive suffering must be alleviated. Contributing to such conservatism are economic and religious motives. The person who is financially committed to conventional transport will find excuses to not accept improved transport for horses. One veterinarian who had just purchased a conventional trailer, on hearing about rear-face transport, spent much of a tour of her farm defending her recent acquisition on such technicalities as its stoutness and construction, its braking system, and the amount of room it allowed the equine passengers to assume their "normal" traveling position of upthrown head, base-wide hindquarters, and weight thrust to the rear!

Many sincere Christians believe that animals are a lower form of life than man, do not have souls, and cannot suffer either physically or mentally to the same degree as humans. Common to each resistance strategy-religious, economic, and "pragmatic" - is the time-honored argument of "tradition." "What was good for Grandad is excellent beyond improvement." 
Even scientifically trained equine practitioners are not immune to the "Grandad syndrome." Firing as a counter-irritant in the treatment of equine lameness was inveighed against by Vegetius as early as $450 \mathrm{AD}$. This peculiar practice ostensibly "strengthens" sub-structures, such as tendons, damaged by overexertion. The warning against creating further damage to already injured tissue was repeated in the first English veterinary text (1565), and in subsequent years.

It has since been demonstrated that firing-which causes long term, excruciating pain to the equine patient - not only risks incurring laminitis, tetanus, suppurative arthritis, synovitis, and septicemia, but it does absolutely nothing to promote healing and in fact weakens the functions of skin and tendons. Recovery is solely due to the rest enforced by the procedure (Eley 1982; McCullagh et al. 1979). ${ }^{2}$

Despite the evidence, more than a few veterinarians will "fire" a horse at the owner's request rather than lose a fee, attempt to educate the owner, or lose the return calls to treat the disastrous side effects (Adamson 1982; Blakeborough 1983; Donaldson 1979). Some veterinarians even persist in the belief that firing is "scientific," not unlike the horsemen of the eighteenth century who cropped their horse's ears and docked the tail at the root on the theory that the horse is like a rose bush: if pruned, it would grow stronger and bigger (Dent 1983).

While conservatism, inertia, and ignorance may account for a proportion of the abuses, both active and passive to animals, there is, I believe, a deeper reason for the willingness, even eagerness, of many horsemen to use coercive tactics and painful caretaking procedures: even when these have been proved patently harmful to both man and beast.

\section{The Psychological Basis of Resistance}

It would seem that many, perhaps most, horsemen fear their horses and feel that they must dominate them. Any procedure requiring the use of force with a horse or subjection of the animals to discomfort and indignity quickly gathers a crowd of onlookers, whether at a rodeo, a show, or in a veterinary clinic. It would seem that the use of coercive tactics, even where these have been shown to be unnecessary, often contributes to the handler's psychological well-being.

For the most part, domestic animals except the horse appear to be regarded as innocuous and unthreatening. The dog has become a symbol of servility and sycophancy. It is literally a bootlicker. Men detest and try to exterminate the dog's wild and free cousins, the wolf, the coyote, the hyena, and the dingo, but love the dog because it is thought to be servile and has been subordinated to man's emotional needs. The same is true, in different ways, of most of the domestic animals.

But the horse, in most cultures including our own, has since the dim epochs of pre-history, been a symbol of freedom and the uncontrollable elements of nature. In the ancient Celtic cultures of Western Europe, which profoundly influenced the culture of British people and their progeny in 
North America and Australasia, the horse was worshipped as a god, and was identified with feminine attributes and values (Gelling and Davidson 1969; Phillips 1976; Ross 1967). These were seen to be in conflict with, and threatening to, the masculine need for order, control, and power over nature and the weak. Even in pagan times the horse came to represent a dark spirit that was feared and that had to be subordinated and subjugated. The rise of the Christian and Islamic religions-with their exaltation of masculinity and their determination to destroy pagan beliefs in which the horse had a powerful, if ambiguous role-intensified the human anxiety toward the horse and the felt need to put the horse in its "proper" place, subordinate to man.

Carl Gustav Jung, the renowned Swiss psychiatrist of the early twentieth century, studied the symbol of the horse in man's unconscious as it affected man's actions. Jung was convinced that the eternal conflict, as he saw it, between masculine and feminine values - between authority, control, and power on the one hand, and freedom, spontaneity, and creativity on the other-was symbolized primarily by the horse (Cregier 1981; Jones 1983).

If this is true-and like Jung, I am convinced that it is-we need look no further for the explanation of man's abuse and mistreatment of the horse, not only in transport, but in other situations as well.

Although there is a greater empathy in our culture between women and horses, we also find many women who seem to derive pleasure from coercing their horses. In my experience, these women tend to extol masculine values and to view their own sex as subordinate and inferior. In one instance, a young woman (who, incidentally, was active in humane society work) had almost been killed while forcing her horse to load into a conventional trailer. This woman refused to consider rear-face transport for her horses, even when it was demonstrated to her that her horses could be loaded and transported easily and comfortably in a rear-face conveyance. Her rationalization was that (a) you have to show the horse who is boss, and (b) if the horse is too comfortable during a trip, it will only get into trouble. There could hardly be a better illustration of the culturally implanted human fear of the horse's natural freedom and spontaneity and the felt need of some men and women to keep this dangerous animal in conditions of subjection and indignity. This woman is an articulate rodeo supporter, especially of the bucking horse performances.

In literature, as in life, the horse has commonly served to represent man's inner conflict between "uncontrolled" instinct and controlled reason. In George MacDonald's Lilith, the horse there symbolizes control of will and imagination, and partial reconciliation of the female abuse of sex (which is power), and the male abuse of sex (which is sensuality).

In his work, The Great Divorce, the English essayist and scholar C.S. Lewis uses the horse as a symbol of the divine steed, or reconciled will and imagination, which can then carry the soul so blessed to God.

Professor George Schoolfield of Yale University, writing from his nearly four decades of familiarity with Scandinavian literature, notes the use of the 
horse as a symbol of this conflict. In nineteenth century Scandinavian novels, a good many of their authors use the horse in this capacity. In Verner von Heidenstam's The Charles Men, or J.V. Jensen's The Fall of the King, the Nietzschean heroes "require horses and either treat them cruelly (as Axel does in the Jensen novel) or in a showily generous fashion (as does Charles in Heidenstam)." In our time, the theme continues.H.C. Branner's The Riding Master, a Danish book written in the 1940s, is a commentary on the Nazi type (Schoolfield, personal communication, 1981).

This inner struggle, between cerebral and visceral, rational and imaginative, mind and spiritual sensation, animus and anima, is only resolved through a triadic reconciliation wherein the two, joined, become a greater thing than either alone. Polar opposites are reconciled in such symbolism as the Trinity, or Yin and Yang, or Logos and Eros, or the marriage union, or the symbol of the centaur during the Golden Age of Athens.

Ray Hunt, reformed from a hell-bent, beat 'em up attitude toward horses, has traveled in Australia and North America demonstrating kindness in gentling and training horses. He wonders if he will ever have any success in demonstrating to the cowboy-whether wearing western boots or English jodhpurs - that the cowboy has misunderstood his own alter ego, that he abuses the very creature on whom he most depends.

As long as mankind suffers from an epidemic proportion of spiritual illiteracy - and we see the wreckage all around us: corpses of exterminated donkeys in the Grand Canyon (New York Times 1984a, b); announcements by Federal authority that wild horses are to be harvested with guns (Gordon n.d.; Wild Horse and Burro Diary n.d; McGrory 1981) - of not coming to terms with its inner polarities, Ray Hunt's crusade has no hope. Selfstyled horsemen, witnessing the amiable meeting, the first-time trust being nurtured, the saddling and riding of previously untouched horses, all within an hour, leave muttering: Kindness to the horse. It just won't work, no matter what this buckaroo says and does (Heminway 1981).

\section{Limits to the Educational Approach}

Education, frequently invoked as a front-line defense in cases involving cruelty, has also clearly failed to deflect flagrant cruelties by authorities who profess to possess an educated background. As we have seen, some veterinarians, and even the British Horse Society, remain unconvinced that firing should be abolished in practice, from their texts, and by law (Drew 1982).

Many educational establishments themselves seemingly require education on animal issues. Those that purport to cultivate a professional attitude toward animal care may consistently refuse to consider courses in applied animal ethology. The absence of such courses, including those in horse behavior, at many veterinary schools handicaps graduating veterinarians. The latter, under the constraints of time, and in their ignorance, may resort to brutal methods of controlling animals, losing their credibility in the eyes of many clients, and certainly with the horses. The chances of handling success on subsequent visits by themselves or another veterinarian are decreased. 
a contributing factor to the gross national product, risks losing an appreciation of the intrinsic nature of the animal. The animal is studied in its natural state only to subsequently corrupt it, whether it is to take advantage of dolphin's locating abilities to plant bombs in enemy harbors, or of sheep flocking behavior to raise and ship them in densely crowded conditions.

\section{Change Strategies}

Legal, political, and to some extent, instructional approaches may help to overcome the apathy that militates against improved animal care. Where legislation is enforced, for example, better care for animals can sometimes be obtained.This evidently occurred when New York State recently passed, and enforced, legislation with reference to improved slaughter horse transport on its highways. But these tools to improvement will not, by themselves, dislodge the deep-seated psycho-cultural obstacles to improved humane care. Conventional handling practices for horses cater to those who derive a satisfaction from a physical assault on their horses - whether it is the cowboymodel for a cigarette company who introduces himself to a strange horse by stunning it with a blow to the muzzle (Chriss 1976), or the performance horseman who uses the whip to draw blood.

Any change in strategy based on legal, empathic, or educational concepts is wasted on these people. The bottom-line approach, too, has limited appeal. The rodeo cowboy is unlikely to treat his own beef cattle as he does those in roping events in the arena, simply because it is not efficient or economical.

Change strategies for the particularly resistant personality might well succeed, however, by offering them a new self-concept (Seabrook, personal communication, 1984). Conversion to improved treatment for animals, and in particular horses, by persons who are already stable names would have a significant impact upon hundreds of average horse owners who follow the herd in all respects. Particularly, macho models, or those who have a very high success profile in the arena-from notable trainers to Olympic-class equestrians - would be the most effective.

Whatever approach, or combinations of approaches are utilized-education, legislation, or role-model-a full and frank assessment of aims frequently reveals the sobering fact that man is not fit to rule a hen-roost. For this reason, English scholar C.S. Lewis wrote "even the authority of man over beast has to be interfered with because it is constantly abused" (Lewis 1975).

Not long ago a humane society brought a case against a fishing bait supplier providing crabs with an inadequate transport environment (Murray 1980). Surely it is past time that we must give as much thought to hauling our horses as we now do to crustaceans!

\section{Endnotes}

${ }^{1}$ North American Editor, Equine Bebavior Joumal, University of Prince Edward Island, Charlottetown, Prince Edward Island, Canada C1A 4P3

${ }^{2}$ See also, KG McCullaugh and IA Silver. 1981. The actual cautery: Myth and reality in the act of firing. Eq. Vet. J. 13(2): 81-84.; Brown et al. 1983. The clinical and experimental studies of tendon injury and healing. Eq. Vet. J. (Suppl. 1). 


\section{References}

Abbott, E. 1979. Investigations into the physiological changes associated with transport in the horse. Annual Repont to the Animal Health Trust. United Kingdom, n.p.

Adamson, P. 1982. Letter to the Editor. Equi. 2(12): 3-4.

Blackshaw, J, Kirk, D and Cregier, S. 1983. A different approach to horse handling based on the Jeffety Method. Int. J. Stud. Anim. Prob. 4(2): 117-23.

Blakeborough, J. 1983. Letter to the Editor. Equi. 3(14): 3.

Branner, HC. 1951. The Riding Master: London: Secker and Warburg.

Caola, G, Ferlazzo, A and Panzera, M. 1984. Livelli sierici di creatinina fosfochinasi in cavalli, dopo trasporto. (Serum creatinine and creatine phosphokinase levels in the horse after transport.) La Clinica Vet. 107: 46-48.

CFHS. 1984. (Canadian Federation of Humane Societies). Relieving pain in lab animals. In: Caring for Animals. 1(2). n.p.

Chriss, N. 1976. Marlboro men spur sales. Moneysworth. Sept. 13.

Cregier, SE. 1981. Alleviating Surface Transit Stress on Horses. Ann Arbor, MI: University Microfilms.

-. 1982. Reducing equine hauling stress. J. Equine Vet. Sci. 2: 186-98.

Dent, A. 1983. Shocking docking. Equi. 3(15):4-7.

Donaldson, RS. 1979. Firing of horses (letter). Vet. Rec. 105: 173-74.

Drew, H. 1982. Letter to the Editor. Equi. 2(12): 4.

Eley, J. 1982. "What the fire will not cure, nothing will cure"?: The truth about firing and blistering. Equi. 2(11): 8-9.

Follmer, D. 1980. Ride, guide and agilize: The gospel according to Monte Foreman. Equus. 40: 26.

Fraser, AF 1982. The nature of cruelty to animals. Equi. 3(13): 28-29.

-. 1984. The behaviour of suffering in animals. Appl. Anim. Beb. Sci. 13:33.

Gelling, P and Davidson, HE. 1969. The Chariot of the Sun: Ritual Symbols of the Northern Bronze Age. New York. pp. 167-72.

Gordon, A. n.d. Looser rules urged for kills of wild horses. Wild Horse and Burro Diary. 20(3): 21.

von Heidenstam, CG. 1920. The Charles Men. New York: Am. Scandinavian. trans, from Swedish by CW Stork.

Jensen, JV. 1933. The Fall of the King. New York: H. Holt and Co. trans. from the Danish by PT Federspiel and Patrick Kirivin.

Jones, B. 1983. Just crazy about horses: The fact behind the fiction. In: Katcher, AH and Beck, AM. eds. New Perspectives on Our Lives with Companion Animals. Philadelphia: Univ. of Pennsylvania Press.

Heminway, J. 1981. The cowboy who respects horses. Quest. 5(5): 22-26, 84-86, 88.

Lewis, CS. 1946. The Great Divorce. London: MacMillan.

-. 1975. Fern-seed and Elephants. Glasgow: Collins. p. 19.

MacDonald G. 1962. Lilith. London: Eerdmans.

McCullagh, KG, Goodship, AE and Silver, IA. 1979. Tendon injuries and their treatment in the horse. Vet. Rec. 105: 54-57.

McGrory, M. 1981. BLM wild horse plans provoke national outrage. Wasbington Star. July. (quoted in Am. Horse Prot. Assoc. Neusletter. Fall 1981: 3).

Messer, NT. 1976. Acute colitis syndrome: Clinical problems in private practice. Amer. Assoc. Equine Practitioners Newsletter. 2: 44-51.

Miller, RM. 1984. Equine Psychology and Its Applications to Veterinary Practice. Paper delivered to the Mid-Coast Veterinary Society. Oct. 4, 1984. San Luis Obispo, CA.

Murray R. 1980. Court case on "cruelty" to crabs. (London). Observer. Nov. 16.

New York Times. 1984a. Burro bonanza. 8 April 1984: 49.

-. 1984b. Doomed burros find baven at Texas ranch. 25 Dec. 1984: 8.

Owen, Rb ap Rb, Fullerton, $J$ and Barnum, DA. 1983. Effects of transportation, surgery, and antibiotic therapy on ponies infected with Salmonella. Am. J. of Vet. Res. 44: 46-50. 
Phillips, GR. 1976. Brigantia: A Mysteriograpby. London: Routledge and Kegan. pp. 189-95.

Ross, A. 1967. Pagan Celtic Britain: Studies in Iconograpby and Tradition. London: Routledge. pp. 321-33.

Sambraus, HH. 1981. Horses: Behavior patterns during transit. Remarks. Report Series. No. SC $81 / 09 / 01$. World Society for the Protection of Animals. London. n.p.

Seabrook, MF. 1984. The psychological interaction between the stockman and his animals and its influence on performance of pigs and dairy cows. Vet. Rec. 115: 84-87.

Veterinary Record. 1984. Comment: Close encounters of an ethological kind. 115: July 28. n.p. Wild Horse and Burro Diary. n.d. Wildlife federation challenged. 19(1): 5.

Wright, M. 1983. The Tbinking Horseman. New South Wales. Self-published. p. 10. 